\title{
The Effect of Pastoralist's Perception Innovation on Livelihood Improvement: Based on Empirical Analysis in the Source Region of Yellow River, China
}

\author{
Yiping Fang ${ }^{1}$ \\ ${ }^{1}$ Institute of Mountain Hazards \& Environment, Chinese Academy of Sciences, Chengdu, China \\ Correspondence: Yiping Fang, Institute of Mountain Hazards \& Environment, Chinese Academy of Sciences, \\ Chengdu 610041, P.R. China. Tel: 86-28-8522-9236. E-mail: ypfang@imde.ac.cn
}

Received: December 14, 2012 Accepted: February 3, 2013 Online Published: February 19, 2013

doi:10.5539/jsd.v6n3p16 URL: http://dx.doi.org/10.5539/jsd.v6n3p16

\begin{abstract}
This paper uses net income per capita, GDP per capita, meat production per capita, and milk production per capita as the proxy indicators to descript the level of pastoralists' livelihood; and grazing capacity (reflecting wealth perception), slaughter rate of livestock, sold rate of livestock (reflecting commodity perception), and composition of female animals in season and death rate of livestock at mating age (reflecting technological perception) as the proxy indicators for description the perceptions of pastoralists. Author builds a relevance model between pastoralist's livelihood and perceptions at both single and multi-factor mode level. The results indicate: (1) from the perspective of pastoralist's livelihood promotion, it is important to emphasize the innovation of conventional commodity idea (resisting slaughter rate of livestock and commercialization), the conventional wealth perception of pastoralists (worship the more livestock possession the wealthier), and establishment advanced management perception (focus on structural adjustment and disaster resisting ability); (2) from the priority perspective of perception innovation, special emphasis should be placed on the controlling the grazing capacity of livestock, and promoting the slaughter and sold rates of livestock; (3) pastoralist's perceptions severely restrict the improvement of pastoralist's livelihood. Based on the findings, recommendations for possible interventions, such as strengthening the skill training, shifting the traditional wealth perception of pastoralists, the conventional commodity perception and establishing advanced management perception are made.
\end{abstract}

Keywords: pastoralist, perception innovation, livelihood improvement, the Source Region of the Yellow River

\section{Introduction}

Perception is a reflection of different social phenomena in various areas (Ferguson \& Bargh, 2004). As a kind of social consciousness, perception comes from social practice, namely, it is directly obtained from knowledge spreading and living practices. Social perception is also one important component of social competence and social success. On one hand, it has been largely assumed that although judgments and feelings can be shaped by factors outside of people's awareness, complex social behavior is determined by people's conscious and deliberately made choice. On the other hand, complex behavior is also automatically shaped and guided by the knowledge that is incidentally activated during perception (Ferguson \& Bargh, 2004). Furthermore, socially competent people must make use of social knowledge and of scripts of social lives in their decision making and acting (Ferguson \& Bargh, 2004).

Despite the study of perception is mainly the mission of sociologist. Recently the distinction of social and natural sciences has been fading, some aspects of other fields remain of interest to perception. In recent year, much interdisciplinary work conformed that the perception of certain actions can lead to the performance of regional development. As mentioned by Ho and Azadi (2010), since the 1980s, a new attitude toward pastoralists has emerged, marked by a conference entitled "The Future of Pastoral Peoples", anthropologists and grassland ecologists placed much emphasis on the importance of the pastoralist emic view and the positive role of pastoralists as social rational producer (Ho \& Azadi, 2010). Consequently, much work has expanded upon this topic, the research advance of pastoralist's perception and development is mainly in the following aspects according to the existing literatures. 


\subsection{Comparative Study of Pastoralists' Cognition on Grassland Degradation}

Researchers have examined the difference of pastoralists' cognition on grass degradation through questionnaire survey in recent year. For example, using two pastoralist groups in different regions of Ethiopia, Abule et al. (2005) compared the cognition characteristics of pastoralists concerning grassland utilization and strategies. Despite the significant difference in two groups of data, most pastoralists acknowledged that the conditions of pastures they lived were poor and believed the three common reasons contributing to the degradation of grassland included overgrazing, drought and sharp growth of population. Thus, they established a strategic framework of grassland management based on three disciplines, i.e. demography, sociology and politics. Again, a survey was conducted in the Borana pastoral areas of southern Ethiopia by Solomon et al. (2007). They argued that all the respondents considered the condition of the rangelands to have declined dramatically over time. Similarly, Ho and Azadi (2010) clarified the differences of the cognition of grassland degradation on basis of 284 pastoralists in six Ningxia counties, China. Their study showed that the majority of respondents believe the rangelands in Ningxia have been degraded, although there are some disparities among the counties that illustrate differing severity of degradation. Also, they addressed the importance of pastoralist's perception on the assessment of grassland degradation.

\subsection{Conservation Effect of Pastoralists' Indigenous Knowledge on Grassland}

Bollig and Schulte (1999) compared the causal relationship between indigenous knowledge and species' grazing value, plant succession and environmental change in two African pastoral societies. Due to the influence of social structure and embedded in ideology, they emphasized the dual effects (positive and adverse) of pastoralists' indigenous knowledge on the grassland management. In Mapinduzi et al. (2003)'s study, they incorporated the indigenous ecological knowledge of the Maasai pastoralists to assess effects of grazing on rangeland biodiversity in northern Tanzania. They concluded that the indigenous system of landscape classification provide a valuable basis for assessing rangeland biodiversity. Similarly, Solomon et al. (2007) also found that the indigenous knowledge of pastoralists integrated with scientific knowledge can be very valuable in the early warning system of environmental changes and appropriate intervention of grassland ecosystem.

\subsection{Causal Relationship between Pastoralists' Environmental Awareness and Grassland Management}

Following the main contributions in the earlier theoretical formulations of the "Tragedy of the Commons" put forward by Hardin (Hardin, 1968), the debate about the positive and negative effect of pastoralists' awareness has been waged (Hardin, 1998; Ostrom, Burger, Field, Norgaard, \& Policansky, 1999). In the African case study, Allsopp et al. (2007) used semi-structured interview approach to identify the causal relationship between pastoralists' environmental awareness and sustainable management of grassland, and emphasized the positive effect of pastoralists' environmental awareness on grassland management. They argued that pastoralists were able to identify the toxicity and un-palatability of some plants, and to classify the grazing areas and decide on daily grazing routes according to grassland conditions, seasons and other elements. Meanwhile, they also addressed the carrying capacity of each area is not considered as a fix parameter but rather as a variable dependent on rainfall; the external intervention of grassland management should consider the environmental awareness of the pastoralists in a proper manner.

\subsection{Influence of Grassland Degradation on Pastoralists' Livelihood}

As survey conducted in two pastoral weredas of Ethiopia by Kassahun et al. (2008), they found that drought, aridity and rangeland degradation have increased over time due to environmental degradation and mismanagement of rangeland resources in the past 60 years (1944-2004). This has influenced the planning and preference of pastoralists for different types of livestock. Poor and very poor households have emerged, and the below-medium wealth rank has disappeared, showing that poverty was becoming a major threat against the sustainability of the livestock production system in this region. Fang et al. (2010a) established a relational model between manual intervention of grassland and pastoralists' welfare in the source region of Yellow River, and analyzed the sensitivity and effecting magnitude of manual intervention on pastoralists' welfare. They suggested that the positive manual intervention of grassland has an obvious effect on pastoralists' livelihood. Fang et al. (2011a) reviewed the positive and negative twofold influences of cryospheric change, especially permafrost change on grassland productivity. Also, they build an adaption framework including pasturing area, livestock industry and livelihood from scale, role and driving force dimensions. In Fang et al. (2011a)'s study, they stressed the importance of the adaption actions that shall be taken to guarantee the sustainability of pastoralist's livelihood in the context of cryospheric change. In the same year, Fang et al. (2011b) challenged the modeling methods of permafrost impact analysis on grassland productivity, and quantified the carrying capacity change of grassland ecosystem in the source region of Yellow River. Due to the overlying influence of natural and 
anthropological elements, the theoretical carrying capacity of grassland in the source region in the past over 20 years has been dropped 11 percent. Furthermore, the importance of financial investment of the government in improving pastoralist's livelihood is emphasized.

Existing literatures indicate that the researchers have not been paid enough attention to the relationship between pastoralist's perception and livelihood until recently. Relevant work focusing on quantitative assessment the influence of pastoralist' perception on livelihood is still very scarce so far. The Tibet-Qinghai plateau is sparsely populated by people whose traditional livelihoods and culture revolve around pastoralism. Owing to the high altitude and the related harsh environment, highly decentralized, sufficiently independent and significantly closed phenomena of production and living system are still very common. Furthermore, pastoralists' livelihoods depend on natural resources, especially the grassland resources. In the condition of traditional economy, it is widely understood by the pastoralists that the indications of wealth are grassland and livestock (Cui, Jiang, Liu, $\& \mathrm{Su}, 2007)$. On the other hand, Qinghai-Tibet Plateau is an ethnically diverse area, with a high proportion of the population represented by Tibetan nationality. Therefore, pastoralists are characterized by the religious beliefs of "quit killing", and the wealth perception of "reluctant to sell and quit killing", indeed, which impacts the slaughter rate of livestock to certain extent. It has become an important factor restraining the development of animal husbandry in Tibetan area (Su, 2011; Wang, Shi, \& Zhang, 2011). After the founding of new China (1949 ), the modern production mode such as commercialization, specialization and socialization has become increasingly significant in the Qinghai-Tibet Plateau over several decades. However, the traditional perceptions of the pastoralists such as "Zhong-mu-qing-shang" (emphasis on animal husbandry and prejudice against commerce), "Zi-ji-zi-zu" (self-sufficiency) and "Kao-tian-yang-xu" (animal raising relying on nature alone) are still very common (Zhang \& Chen, 2007), thus such perception tremendously obstructing the sustainable development of the pastoral areas (Qin, 2007; An, 2001; Nan, 2002). Therefore, to balance the interests of pastoralists, and to change conservative awareness of pastoralists are becoming increasing importance.

The main targets of this paper are: (1) to select proxy indicators describing pastoralist's perception and livelihood, and establish a relevance model between pastoralist' perception and livelihood; (2) to quantify the influence magnitude of pastoralist's perception on livelihood; (3) to emphasize the importance of pastoralist's perception innovation. The chapters of the paper are organized as follows: methods; results and discussion; conclusions and management implications.

\section{Methods}

\subsection{Study Area}

The source region of Yellow River is located in the hinterland of Qinghai-Tibet Plateau and southeast of Qinghai Province, it birders the Anyemaqen Mountains on the north and the Bayankela Mountains on the south. The latitude range is from $33^{\circ} 00^{\prime}$ to $35^{\circ} 35^{\prime} \mathrm{N}$, the longitude range from $96^{\circ} 00^{\prime}$ to $99^{\circ} 45^{\prime} \mathrm{E}$, and with a total catchment area of $7.46 \times 104 \mathrm{~km}^{2}$. The source region is characterized by a typical inland plateau climate and unique alpine ecosystem, with mean elevation from $4400 \mathrm{~m}$ to $4500 \mathrm{~m}$ (Fang, Qin, \& Ding, 2010b) (Figures 1-3).

The administrative divisions include most regions of 6 counties in Golog Tibetan Autonomous Prefecture, namely Maqin, Gande, Banma, Jiuzhi, Dari and Maduo, and a small region in Qumalai County of Yushu Tibetan Autonomous Prefecture. According to the administrative data, by the end of 2009, there were a total households and population of 60176 and 194000 respectively, and most are ethnic Tibetan nationality in the source region. The average population of each household was 3.2 and the population density is $1.5\left(\right.$ person $\left./ \mathrm{km}^{2}\right)$. The grassland covers an area of 9.69 million hectares, and the total number of livestock at the end of year reached 5.863 million units of sheep. The grazing capacity of grassland area is $0.6\left(\right.$ sheep unit $\left./ \mathrm{hm}^{2}\right)$. The animal husbandry is not only a traditional industry of this region but also the pillar sector of the regional economy. Meanwhile, it is also a main source of economic and physical welfares of pastoralist. The share of added value of animal husbandry in the GDP reached $35.5 \%$ and the net income per capita of pastoralists was approximately RMB 2450 (about 389 US\$), which was $47.3 \%$ of the average net income of rural residents in China and $73.2 \%$ of the average net income of Qinghai Province (Qinghai Provincial Statistics Bureau, 2010). 

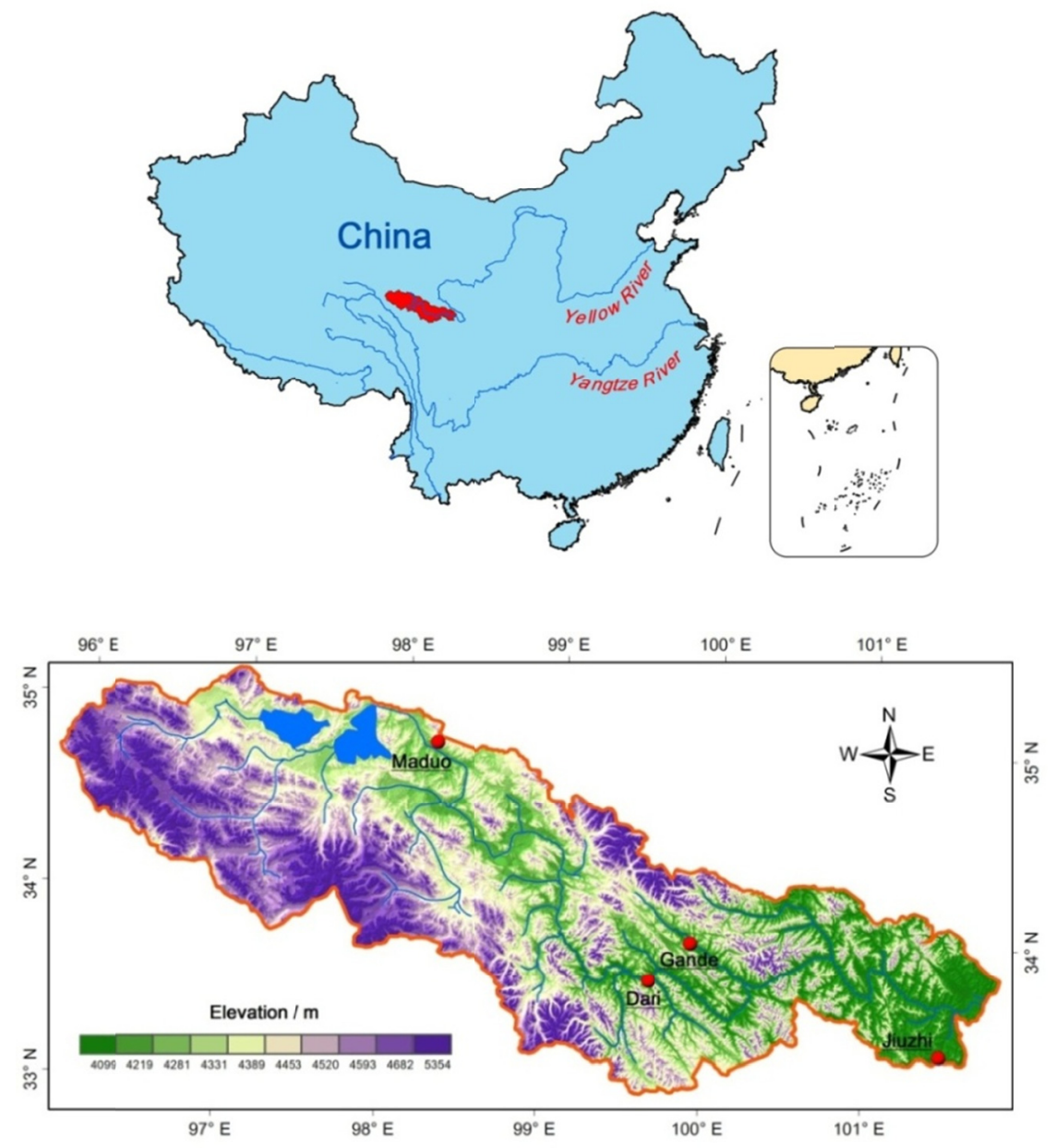

Figure 1. The geographical location of study area

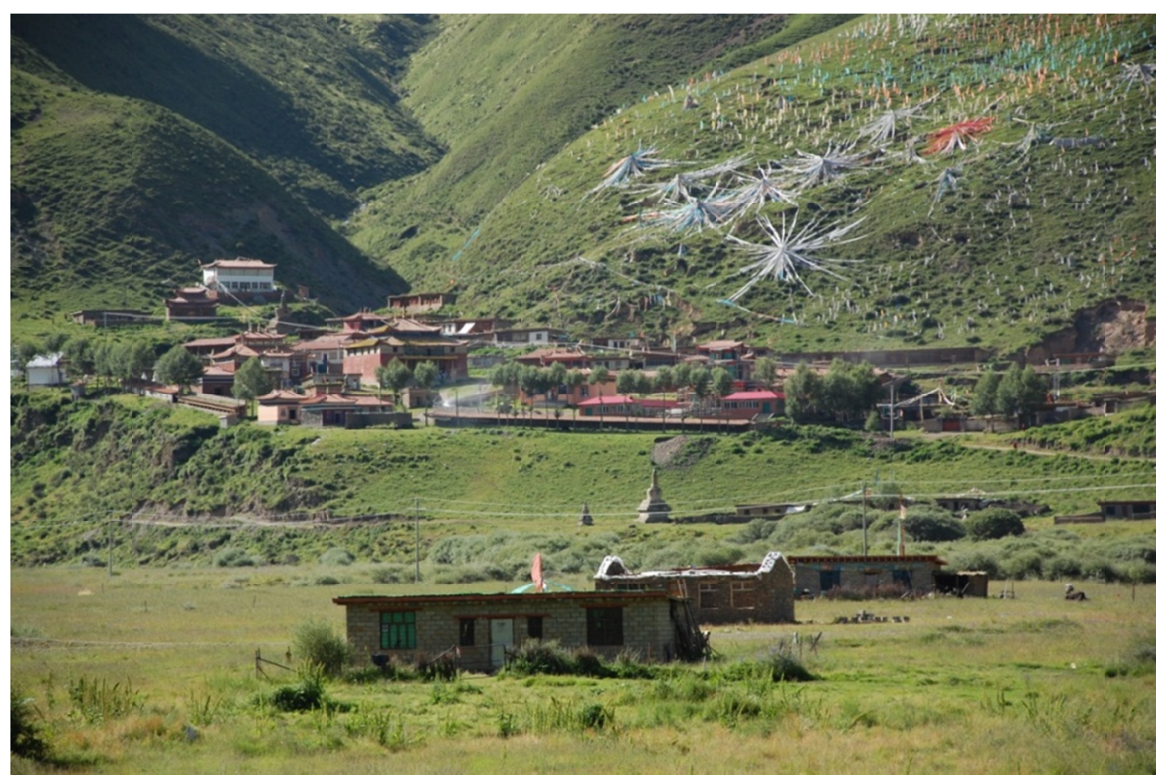

Figure 2. The pastoralist's settlement in Banma County (Photo by Yiping Fang, 2009) 


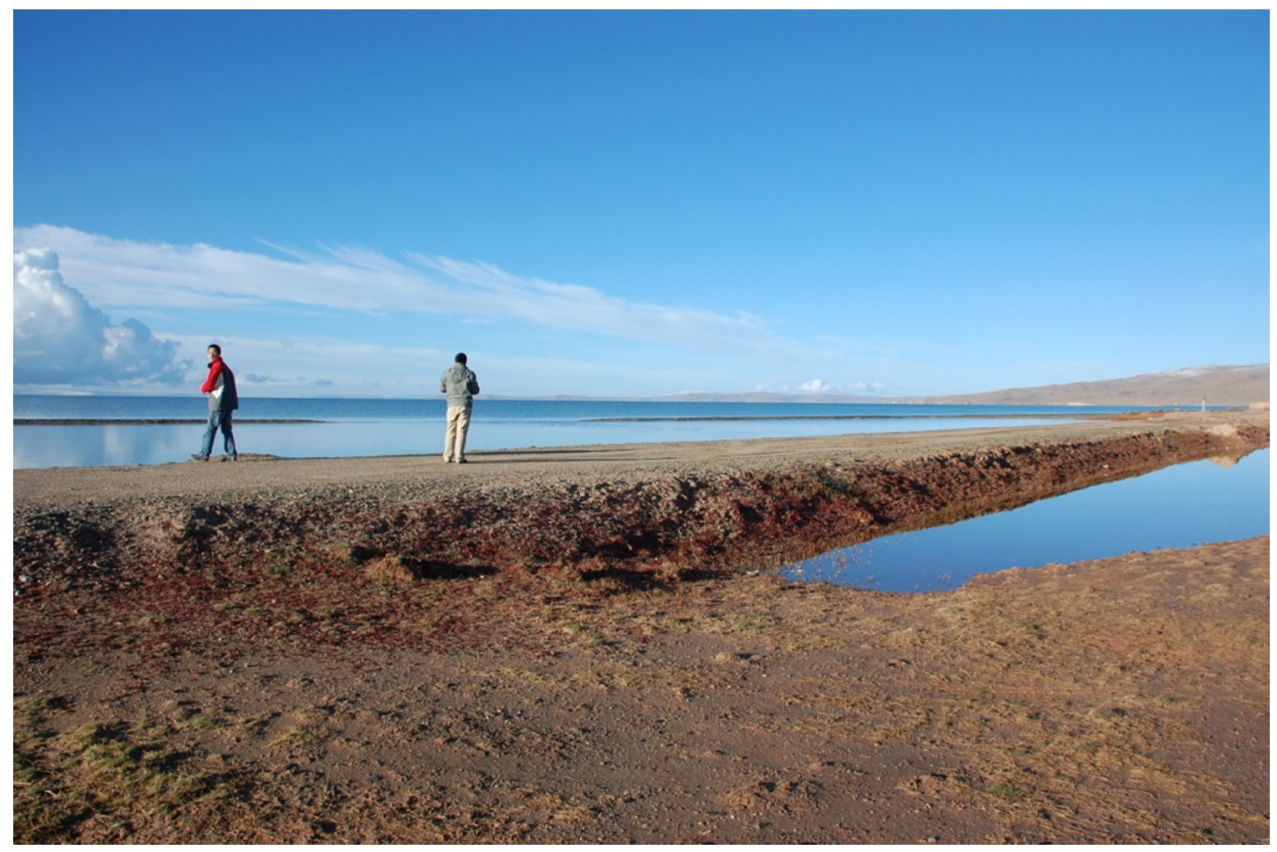

Figure 3. The Eling Lake in Maduo County (Photo by Yiping Fang, 2008)

\subsection{Indicators Selection and Data Collection}

Welfare refers to utility and satisfaction obtained by individuals (Pigou, 1962). Some scholars have clamed that welfare cannot only is the safety, richness and happiness of material life but also a spiritual and moral status. It is the basis, opportunity and condition as well as various necessary efforts exerted in daily life for an individual to initiatively pursue a happy life in the world (Ichibangase, 1998). Although consensus has not been reached concerning the conceptualization of welfare, and there has been an ongoing debate regarding the measurement of welfare for many years (Sen, 1976; Clarke \& Islam, 2003), however, there seems to be wide agreement that value judgment of welfare is the core of welfare economics (Clarke \& Islam, 2003). In practice, there are a significant number of accounting methods with respect to local welfare measures, the improvement of individual economic and material welfare is an important target of sustainable livelihood strategy (Chambers, 1986; Singh \& Hiremath, 2010). Undoubtedly, the emphasis on the promotion of pastoralists' individual income and material conditions is a critical path and driving force of livelihood sustainability (Chambers \& Conway, 1992; United Nations General Assembly, 1997). Considering the feasibility, data availability and the representativeness of indicators, we use net income per capita as the economic welfare proxy of pastoralists, GDP per capita to represent the social welfare indicator of pastoralists, meat and milk productions per capita (main food sources of pastoralists in plateau) to represent the material welfare indicators of pastoralists (Fang, Qin, \& Ding, 2010a). At the same time, we choose the proxies of economic and material welfare to describe the livelihood level of pastoralists in the source region.

As noted by many scholars, perception is a relatively abstract concept which cannot be accurately measured by using quantitative methods. The content of perception involves not only cognitive ability but also values and code of conduct (Ferguson \& Bargh, 2004). However, in the source region of Yellow River, the wealth perception (worship the more livestock possession the wealthier), commodity perception (resisting livestock slaughter and commercialization) and technological perception (indifferent to structural adjustment and disaster resisting ability) of the pastoralists are still colored by outdated stereotypes due to the restraints of history and the environment. Thus, some researchers argued for the need of new perception modes to cope with the sustainable development in the pastoral areas. In order to highlight main characteristics of the pastoralists' perceptions in this region, we try to select grazing capacity (reflecting wealth perception), slaughter and sold rates of livestock (reflecting commodity perception), and composition of female animals and death rate of livestock at mating age (reflecting technological perception) as proxy indicators of pastoralist's perceptions, and to establish a relevance model between pastoralist's livelihood and perception. 
The statistical data is from "Golog 50 Years" edited by Statistical Bureau of Golog Tibetan Autonomous Prefecture of Qinghai Province, and statistical yearbook of Golog and Yushu Tibetan Autonomous Prefectures; the time scale of data is from 1982 to 2007.

\subsection{Model Estimate and Testing}

\subsubsection{Single Factor Model Estimate and Testing}

We take GDP per capita, net income per capita, meat and milk productions per capita as dependent variables (livelihood indicators); grazing capacity, slaughter and sold rates of livestock, composition of female animals in season and death rate of livestock at mating age as independent variables (perception indicators) respectively. Figures 4-7 reveal that there is a relatively obvious quadratic nonlinear relation between the livelihood and perception indicators. Suppose that, given most general quadratic function estimation as our single factor model, that is:

$$
y=\beta x^{2}+\lambda x+\varepsilon
$$

Where, $y$ refers to dependent variable (pastoralist's livelihood) while $x$ refers to independent variable (pastoralist's perception). $\beta, \lambda, \varepsilon$ are unknown coefficients to be determined respectively.

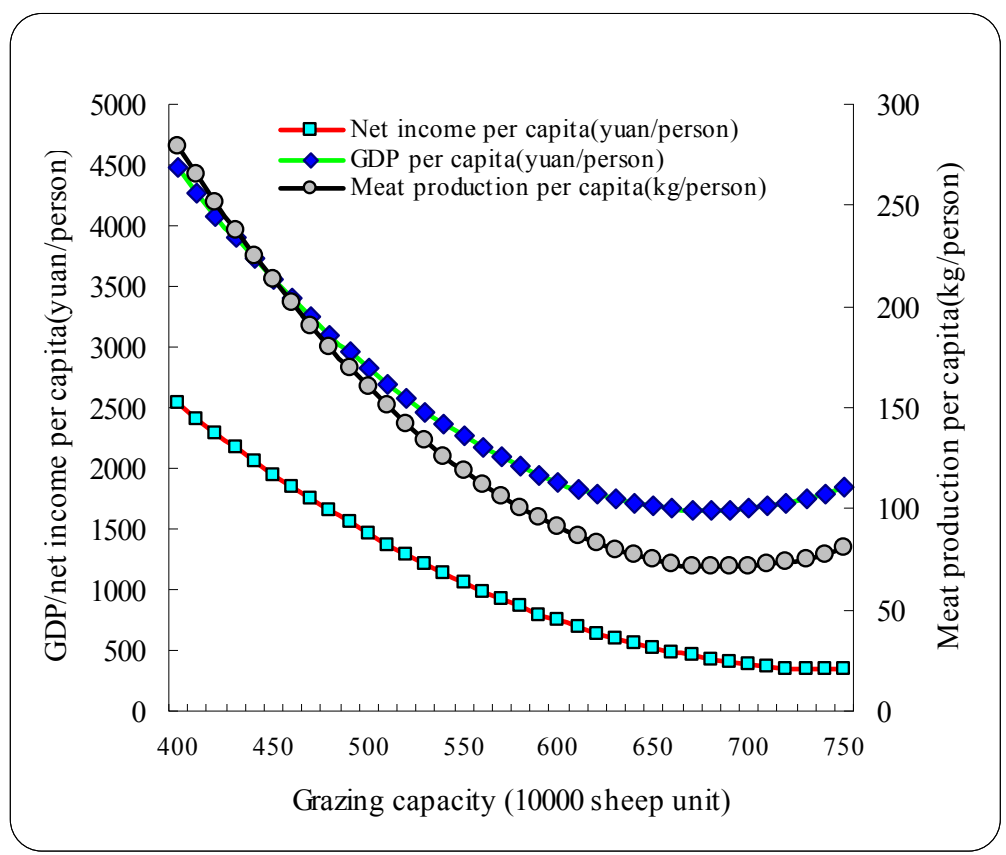

Figure 4. Grazing capacities of livestock vs. livelihood improvement 


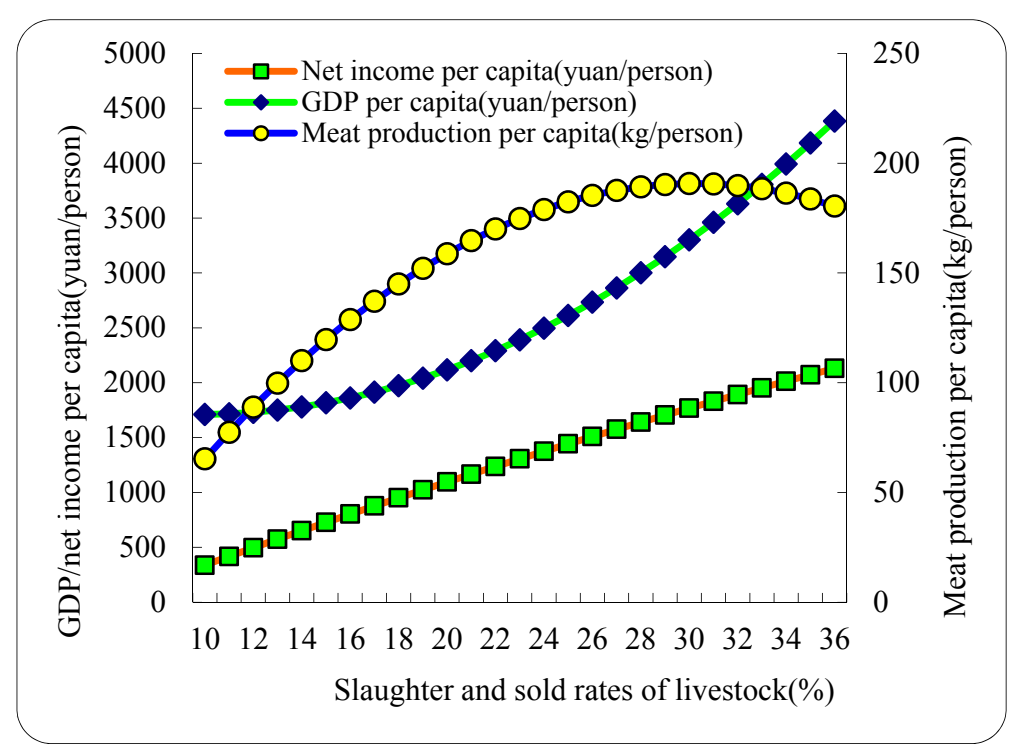

Figure 5. Slaughter and sold rates of livestock vs. livelihood improvement

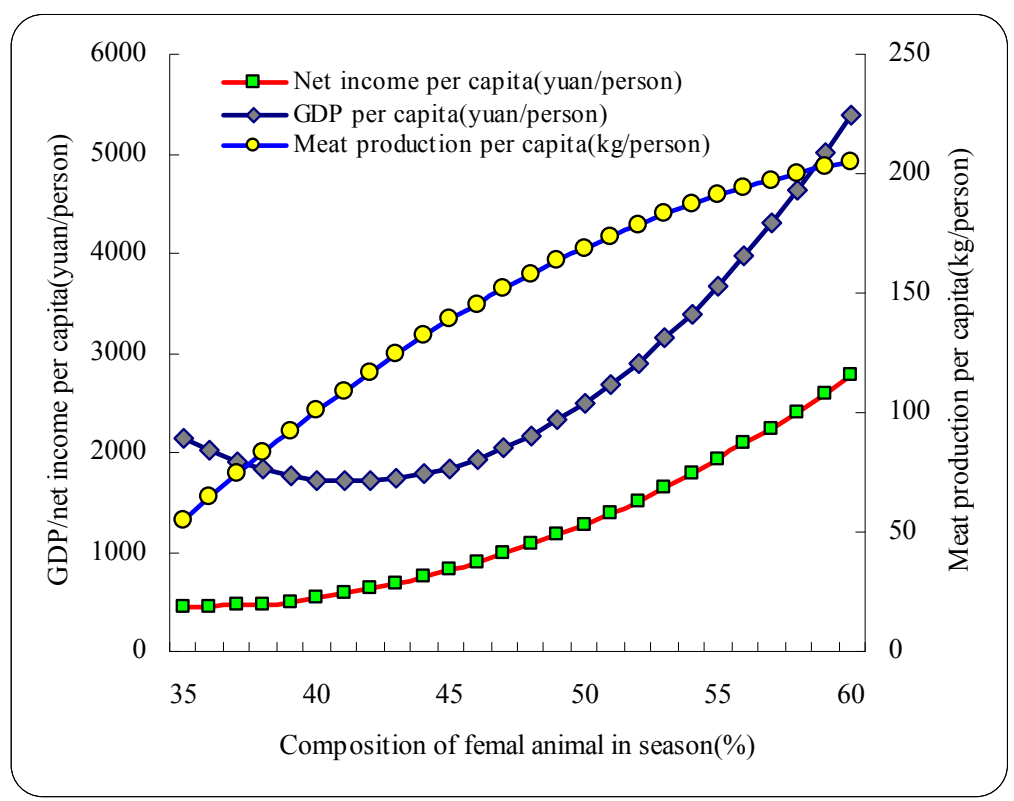

Figure 6. Composition of female animal in season vs. livelihood improvement 


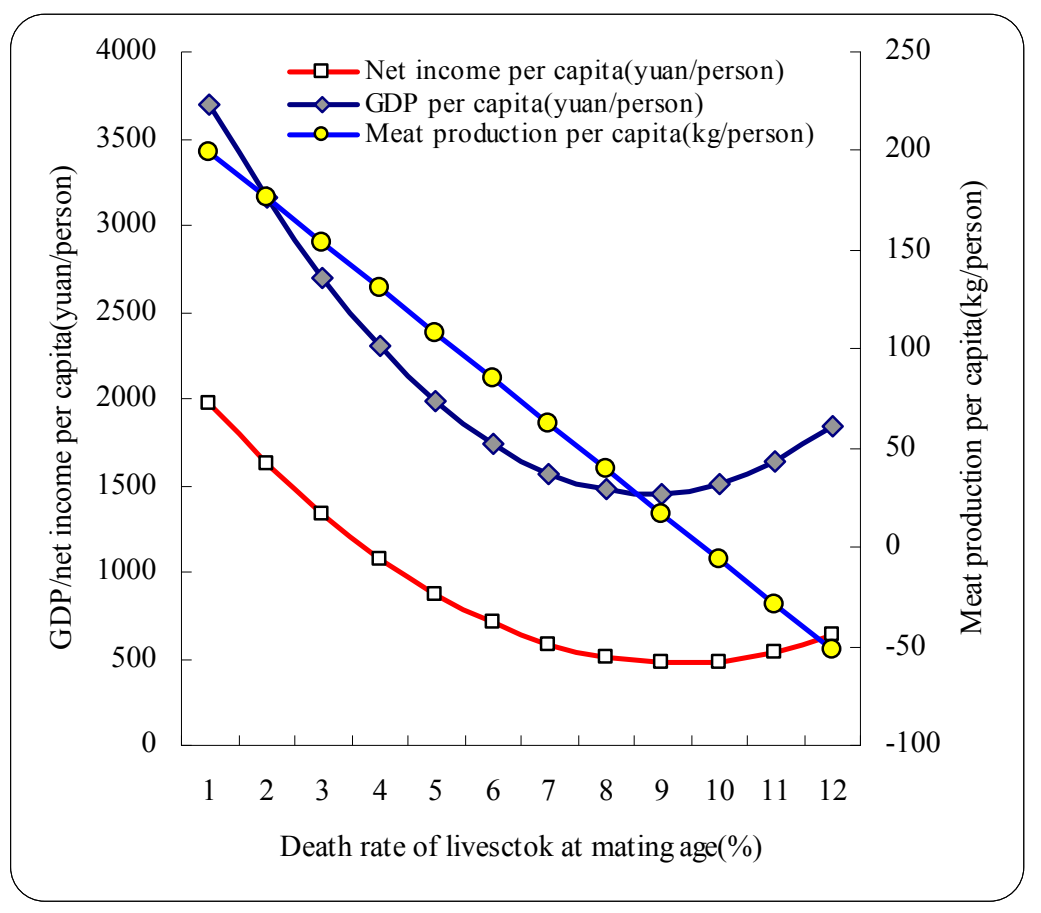

Figure 7. Death rates of livestock at mating age vs. livelihood improvement

Table 1. Statistic testing of single factor regression function ( $F$ testing)

\begin{tabular}{|c|c|c|c|c|c|c|}
\hline $\begin{array}{c}\text { Livelihood } \\
\text { variables(dependent) }\end{array}$ & $\begin{array}{c}\text { Perception } \\
\text { variables(independent) }\end{array}$ & $\begin{array}{l}\text { Goodness of } \\
\text { fit test }\left(R^{2}\right)\end{array}$ & $F$-value & Significance & $\begin{array}{l}F_{0.05 \text {-value }} \\
(\alpha=0.05)\end{array}$ & $\begin{array}{l}\text { Identification of } \\
\text { Sig. }\left(F>F_{0.05}\right)\end{array}$ \\
\hline \multirow[t]{4}{*}{ GDP per capita } & $\begin{array}{c}\text { Grazing capacity of } \\
\text { livestock (10000sheep) }\end{array}$ & 0.418 & $5.755^{* *}$ & 0.013 & 4.28 & yes \\
\hline & $\begin{array}{c}\text { Slaughter and sold rates of } \\
\text { livestock }(\%)\end{array}$ & 0.962 & $205.313^{* * *}$ & 0.000 & 4.28 & yes \\
\hline & $\begin{array}{c}\text { Composition of female } \\
\text { animal in season }(\%)\end{array}$ & 0.967 & $234.726^{* * *}$ & 0.000 & 4.28 & yes \\
\hline & $\begin{array}{l}\text { Death rate of livestock at } \\
\text { mating age }(\%)\end{array}$ & 0.597 & $11.841^{* * *}$ & 0.001 & 4.28 & yes \\
\hline \multirow[t]{4}{*}{ Net income per capita } & $\begin{array}{l}\text { Grazing capacity of } \\
\text { livestock }(10000 \text { sheep })\end{array}$ & 0.759 & $34.579^{* * *}$ & 0.000 & 4.28 & yes \\
\hline & $\begin{array}{c}\text { Slaughter and sold rates of } \\
\text { livestock }(\%)\end{array}$ & 0.964 & $293.795^{* * *}$ & 0.000 & 4.28 & yes \\
\hline & $\begin{array}{c}\text { Composition of female } \\
\text { animal in season }(\%)\end{array}$ & 0.950 & $208.885^{* * *}$ & 0.000 & 4.28 & yes \\
\hline & $\begin{array}{l}\text { Death rate of livestock at } \\
\text { mating age }(\%)\end{array}$ & 0.692 & $24.755^{* * *}$ & 0.000 & 4.28 & yes \\
\hline \multirow[t]{4}{*}{$\begin{array}{l}\text { Meat production per } \\
\text { capita }\end{array}$} & $\begin{array}{l}\text { Grazing capacity of } \\
\text { livestock (10000sheep) }\end{array}$ & 0.883 & $82.897^{* * *}$ & 0.000 & 4.28 & yes \\
\hline & $\begin{array}{c}\text { Slaughter and sold rates of } \\
\text { livestock }(\%)\end{array}$ & 0.944 & $186.678^{* * *}$ & 0.000 & 4.28 & yes \\
\hline & $\begin{array}{l}\text { Composition of female } \\
\text { animal in season }(\%)\end{array}$ & 0.867 & $71.557^{* * *}$ & 0.000 & 4.28 & yes \\
\hline & $\begin{array}{l}\text { Death rate of livestock at } \\
\text { mating age }(\%)\end{array}$ & 0.635 & $19.129^{* * *}$ & 0.000 & 4.28 & yes \\
\hline \multirow[t]{4}{*}{$\begin{array}{l}\text { Milk production per } \\
\text { capita }\end{array}$} & $\begin{array}{l}\text { Grazing capacity of } \\
\text { livestock (10000sheep) }\end{array}$ & 0.080 & 0.962 & 0.398 & 4.28 & No \\
\hline & $\begin{array}{c}\text { Slaughter and sold rates of } \\
\text { livestock }(\%)\end{array}$ & 0.439 & $8.609^{* * *}$ & 0.002 & 4.28 & yes \\
\hline & $\begin{array}{l}\text { Composition of female } \\
\text { animal in season }(\%)\end{array}$ & 0.153 & 1.993 & 0.160 & 4.28 & No \\
\hline & $\begin{array}{l}\text { Death rate of livestock at } \\
\text { mating age }(\%)\end{array}$ & 0.148 & 1.910 & 0.172 & 4.28 & No \\
\hline
\end{tabular}

Note: Asterisks indicate: significance levels: $* * * 1 \%$ level, $* * 5 \%$ level and $* 10 \%$ level. 
Table 2. Statistic testing of single factor regression coefficients ( $t$ testing)

\begin{tabular}{|c|c|c|c|c|}
\hline \multirow{2}{*}{$\begin{array}{c}\text { Livelihood } \\
\text { variables(dependent) }\end{array}$} & \multirow{2}{*}{$\begin{array}{c}\text { Perception } \\
\text { Variables(independent) }\end{array}$} & \multicolumn{3}{|c|}{ Coefficients, standard errors and significance level } \\
\hline & & $\beta$ & $\lambda$ & $\varepsilon$ \\
\hline \multirow[t]{8}{*}{ GDP per capita } & \multirow{4}{*}{$\begin{array}{l}\text { Grazing capacity of } \\
\text { livestock(10000sheep) } \\
\text { Slaughter and sold } \\
\text { rates of livestock (\%) }\end{array}$} & 0.036 & -48.933 & 18287.204 \\
\hline & & $(0.056)$ & $(62.482)$ & $(17187.730)$ \\
\hline & & $3.888^{* * *}$ & $-75.987^{*}$ & $2081.629^{* * * *}$ \\
\hline & & $(0.935)$ & $(44.053)$ & $(476.366)$ \\
\hline & \multirow{2}{*}{$\begin{array}{l}\text { Composition of female } \\
\text { animal in season }(\%)\end{array}$} & $10.643^{* * *}$ & $-880.905^{* * *}$ & $19934.358^{* * *}$ \\
\hline & & $(1.394)$ & $(133.482)$ & $(3160.876)$ \\
\hline & \multirow{2}{*}{$\begin{array}{l}\text { Death rate of livestock } \\
\text { at mating age }(\%)\end{array}$} & $37.208^{* * *}$ & $-652.173^{* * *}$ & $4311.893^{* * *}$ \\
\hline & & $(12.160)$ & $(162.490)$ & $(409.085)$ \\
\hline \multirow{8}{*}{$\begin{array}{l}\text { Net income per } \\
\text { capita }\end{array}$} & \multirow{2}{*}{$\begin{array}{l}\text { Grazing capacity of } \\
\text { livestock(10000sheep) }\end{array}$} & 0.015 & -23.751 & $9569.503^{* *}$ \\
\hline & & $(0.014)$ & $(16.142)$ & $(4585.296)$ \\
\hline & \multirow{2}{*}{$\begin{array}{l}\text { Slaughter and sold } \\
\text { rates of livestock (\%) }\end{array}$} & -0.430 & $88.694^{* * *}$ & $-506.956^{* *}$ \\
\hline & & $(0.490)$ & $(21.886)$ & $(215.968)$ \\
\hline & \multirow{2}{*}{$\begin{array}{l}\text { Composition of female } \\
\text { animal in season }(\%)\end{array}$} & $3.738^{* * *}$ & $262.346^{* * * *}$ & $5051.451^{* *}$ \\
\hline & & $(0.922)$ & $(86.588)$ & $(2003.418)$ \\
\hline & \multirow{2}{*}{$\begin{array}{l}\text { Death rate of livestock } \\
\text { at mating age }(\%)\end{array}$} & $21.787^{* * *}$ & $-404.388^{* * * *}$ & $2346.796^{* * *}$ \\
\hline & & $(6.136)$ & $(84.050)$ & $(222.711)$ \\
\hline \multirow{8}{*}{$\begin{array}{l}\text { Meat production per } \\
\text { capita }\end{array}$} & \multirow{2}{*}{$\begin{array}{l}\text { Grazing capacity of } \\
\text { livestock(10000sheep) }\end{array}$} & $0.003^{* * *}$ & $-3.443^{* * *}$ & $1256.360^{* * * *}$ \\
\hline & & $(0.001)$ & $(0.859)$ & $(244.020)$ \\
\hline & \multirow{2}{*}{$\begin{array}{l}\text { Slaughter and sold } \\
\text { rates of livestock (\%) }\end{array}$} & $-0.307^{* * *}$ & $18.556^{* * * *}$ & $-89.578^{* * * *}$ \\
\hline & & $(0.046)$ & $(2.076)$ & $(20.484)$ \\
\hline & \multirow{2}{*}{$\begin{array}{l}\text { Composition of female } \\
\text { animal in season }(\%)\end{array}$} & -0.110 & 16.857 & -402.238 \\
\hline & & $(0.115)$ & $(10.749)$ & $(249.743)$ \\
\hline & \multirow{2}{*}{$\begin{array}{l}\text { Death rate of livestock } \\
\text { at mating age }(\%)\end{array}$} & $1.118^{* *}$ & $-23.917^{* * *}$ & $222.122^{* * * *}$ \\
\hline & & $(0.511)$ & (6.994) & (18.532) \\
\hline \multirow{8}{*}{$\begin{array}{l}\text { Milk production per } \\
\text { capita }\end{array}$} & \multirow{2}{*}{$\begin{array}{l}\text { Grazing capacity of } \\
\text { livestock(10000sheep) }\end{array}$} & 0.001 & -1.381 & $671.848^{* *}$ \\
\hline & & $(0.001)$ & $(1.132)$ & $(321.435)$ \\
\hline & \multirow{2}{*}{$\begin{array}{l}\text { Slaughter and sold } \\
\text { rates of livestock (\%) }\end{array}$} & $-0.287^{* * * *}$ & $12.543^{* * *}$ & $152.066^{* * *}$ \\
\hline & & $(0.069)$ & (3.099) & $(30.578)$ \\
\hline & \multirow{2}{*}{$\begin{array}{l}\text { Composition of female } \\
\text { animal in season }(\%)\end{array}$} & $-0.268^{*}$ & $24.894^{*}$ & -298.309 \\
\hline & & $(0.136)$ & $(12.792)$ & $(295.976)$ \\
\hline & \multirow{2}{*}{$\begin{array}{l}\text { Death rate of livestock } \\
\text { at mating age }(\%)\end{array}$} & -0.580 & 6.467 & $259.513^{* * *}$ \\
\hline & & $(0.367)$ & $(5.023)$ & $(13.310)$ \\
\hline
\end{tabular}

Note: Asterisks indicate: significance levels: $* * * 1 \%$ level, $* * 5 \%$ level and $* 10 \%$ level.

The data in parenthesis present standards error.

Statistical testing results are listed in Table 1 and Table 2 respectively. Based on single factor model, Table 1 illustrates that besides milk production per capita, the other 3 key indicators (i.e. GDP per capita, net income per capita and meat production per capita) are significantly related to the perception indicators of pastoralists (i.e. grazing capacity, slaughter and sold rates of livestock, composition of female animals in season, and death rate of livestock at mating age). Regression functions are significant at $\alpha=0.01$ level, the coefficient $\mathrm{R}$ is more than 0.7. Obviously, livelihoods of pastoralists can be explained by 4 perception indexes selected. Table 2 is the coefficients estimate of regression functions. Table 2 shows that besides grazing capacity of livestock, other 3 perception indicators (i.e. slaughter and sold rates of livestock, composition of female animals in season, and death rate of livestock at mating age) have relatively strong correlation with livelihood indicators. Most of regression coefficients pass the t-test, and the significance level of most indexes is above $95 \%$. Therefore, the changes of indicators like slaughter and sold rates of livestock, composition of female animals in season, and death rate of livestock at mating age will directly trigger the fluctuation of welfare levels including per capita income of pastoralists and output of red meat and milk. In other words, from the perspective of single factor, the pastoralist's perception innovation has a direct impact on the promotion of livelihood.

\subsubsection{Multi-Factors Model Estimate and Testing}

Livelihood improvement is, however, almost always caused by multiple perception factors. Estimating the joint effects of multiple perceptions is of special importance for further understanding the effects of multiple factors combination on livelihood improvement, this section is an attempt to do so. We employed the multivariate linear regress method to establish the relationship between livelihood improvement indicators (e.g. GDP per capita, net income per capita, meat and milk productions per capita) and perception indicators (e.g. grazing capacity, 
slaughter and sold rates of livestock, composition of female animals in season, and death rate of livestock at mating age) respectively. Table 3 shows the statistics results of the 4 selected perception factors (e.g. perception indicators) to each of the three livelihood categories (e.g. GDP per capita, net income per capita, meat and milk productions per capita). From Table 3, a higher slaughter and sold rates of livestock is associated with an increase in the net income per capita, and GDP per capita. The grazing capacity of livestock quite understandably reduces the net income per capita, and meat production per capita, it is consistent with the result of single factor analysis mentioned above, this results indicate that overgrazing on grasslands has happened in this area, overgrazing severely hurts the entire grassland biome, thus further affect the livelihoods of local pastoralists. It is very surprising that a higher grazing capacity of livestock increases the GDP per capita. This might be the reason that the number of livestock is the main basis and source of accounting GDP. On the contrary, the impact the composition of female animal in season, and the death rate of livestock at mating age on pastoralist' livelihood improvement is not significant.

Table 3. Statistic testing of multiple factors regression

\begin{tabular}{cccc}
\hline & Net income per capita & GDP per capita & Meat production per capita \\
$\begin{array}{c}\text { Grazing capacity of } \\
\text { livestock (10000sheep) }\end{array}$ & $-1.210(0.764)$ & $1.257^{* * *}(0.439)$ & $-0.871^{* *}(0.423)$ \\
$\begin{array}{c}\text { Slaughter and sold rates } \\
\text { of livestock (\%) }\end{array}$ & $1.410^{* *}(0.526)$ & $0.850^{* *}(0.323)$ & $0.280(0.291)$ \\
$\begin{array}{c}\text { Composition of female } \\
\text { animal in season (\%) }\end{array}$ & $-0.517(0.972)$ & $1.420^{* *}(0.649)$ & $0.637(0.539)$ \\
$\begin{array}{c}\text { Death rate of livestock } \\
\text { at mating age (\%) }\end{array}$ & $0.118(0.149)$ & $0.088(0.084)$ & $-0.020(0.083)$ \\
$\begin{array}{c}\text { Constant } \\
R^{2}\end{array}$ & $12.158^{*}(6.765)$ & $-8.307^{* *}(3.937)$ & $7.168^{*}(3.747)$ \\
$F$ & 0.904 & 0.938 & 0.903 \\
\hline
\end{tabular}

Note: Asterisks indicate: significance levels: $* * * 1 \%$ level, ${ }_{* *} 5 \%$ level and $* 10 \%$ level.

The data in parenthesis present standards error.

\section{Results and Discussion}

In order to deepen the understanding of the influence of pastoralist's perception on the livelihood, and to reveal the quantitative relation between pastoralist's perception and livelihood, it is necessary to conduct analysis from indicator level one by one. Therefore, further discussion lays stress on three aspects of perception indexes, which are wealth perception (grazing capacity), commodity perception (slaughter and commodity rates) and technological perception (livestock structure and disaster resisting ability). Owing to the relation between milk production per capita and perception indexes selected is not significant based on statistical analysis (Tables 1,2). Therefore, it will be eliminated in the further discussion.

\subsection{Results and Discussion Based on Single Factor Model}

\subsubsection{Grazing Capacity of Livestock and Pastoralist's Livelihood}

From the perspective of correlation between grazing capacity and pastoralist's livelihood, despite a low correlation coefficient between GDP per capita and grazing capacity $(\mathrm{R}=0.647)$, the significance levels between pastoralist's net income per capita and grazing capacity $(\mathrm{R}=0.859)$, and between pastoralist's meat production per capita and grazing capacity $(\mathrm{R}=0.940)$ are very high. Besides, Figure 4 clearly indicates that 3 livelihood indicators, i.e. GDP per capita, pastoralist's net income per capita and meat production per capita, present an obvious declining trend with the increase of grazing capacity. Figure 4 also shows that the gradient of the trend curve of net income per capita is relatively steep, indicating the strongest negative effect of grazing capacity on pastoralist's net income per capita. The influence of grazing capacity on meat production per capita comes next. The dynamic curve of GDP per capita is relatively flat, representing a relatively weak effect of grazing capacity on GDP per capita. The reverse relation between grazing capacity and pastoralist's livelihood implies that the marginal benefit of grazing capacity of the grassland in this region is falling down. In other words, the bigger the grazing capacity is, and the lower the promoting efficiency of pastoralist's livelihood will be. The possible causes are that: on the one hand, due to the influence of climatic change, the grassland degradation causes the 
continuous decline of the livestock carrying capacity of the grassland (Kang et al., 2011; Wang, Li, \& Hu, 2009; Chen, Wang, \& Zhou, 2008; Zeng \& Feng, 2007; Wang, Ren, \& Yuan, 2006); on the other hand, the rapidly increase of population, overgrazing, and improper reclamation, the imbalance between forage supply and livestock needs has occurred mainly in the source region of the Yellow river (Qian et al., 2007; Fang et al., 2010b). Ren et al. (2009) has also further demonstrated from an experimental perspective that the height, coverage and ground biomass of meadows presented a significant declining trend with the increase of grazing intensity. Apparently, the proper reduction of the grazing capacity is an effective approach to promote pastoralist's livelihood capacity. However, subject to the profound influence of conventional perceptions of pastoralists, the livestock inventory has always been seen as a symbol of pastoralist families' wealth. Therefore, pastoralists' wealth perception of innovation shall be stressed, and gradually reduce the raising quantity of livestock.

\subsubsection{Commodity Rate of Livestock and Pastoralist's Livelihood}

Considering from the correlations among slaughter and sold rates of livestock and livelihood, the correlation coefficients (R) between GDP per capita, net income per capita, meat production per capita, and the slaughter and commodity rates of livestock are all above 0.97 . Figure 5 reveal that with the continuous enhancement of slaughter and commodity rates of livestock, GDP per capita, pastoralist's net income per capita and meat production per capita rapidly increase. Figure 5 also shows that the curve gradient of pastoralist's net income per capita is very obvious, presenting an almost straight-line growth, which indicates the maximal positive effect of slaughter and sold rates of livestock on pastoralist's net income per capita. The positive relations between commodity rate of livestock and pastoralist's livelihood promotion indicate that slaughter and sold rates of livestock is a most direct and efficient driving factors for the promotion of pastoralist's livelihood. The conventional perceptions of pastoralists (e.g. only pursue the stocking number of livestock instead of the increase of livestock commodities, and equalize the possession of livestock as wealth) in the source region have a tremendous impact on pastoralist' livelihood improvement for a long time (Su, 2011). The main cause of such fixed perceptions of pastoralists is that keeping a relatively high livestock inventory means a relatively low risk of pastoralists' daily income, living materials (meat and milk) and food accumulation. In fact, several recent articles provide support for this hypothesis (Hendricks, Midgley, Bond, \& Novellie, 2004; Allsopp, Laurent, Debeaudoin, \& Samuels, 2007; Johannesen \& Skonhoft, 2011). Therefore, the widespread adoption of pastoralist's perception innovation in the source region of Yellow River, such as guiding pastoralists to establish commodity awareness, changing their perception of "reluctant to sell and quit killing" to improve the livestock product circulation, and activating the product market of livestock to increase pastoralists' income and material welfare was a actively response to sustainable livelihood of pastoralists and poverty reduction.

\subsubsection{Composition of Female Animals in Season and Pastoralist's Livelihood}

According to the relation between structure of female animals and livelihood, we find the related coefficients between GDP per capita, net income per capita, meat production per capita and composition of female animals in season are all above 0.95 . Although the livestock structure includes not only breed structure but also scale and gender structures, the composition of female animals in season is only selected here as the key proxy of livestock structure for discussion. It is widely understood that male animals are only used for hybridization (natural and manual). From the perspective of pastoralists' living demand, yaks are the main sources for Tibetan pastoralists to maintain a self-sufficiency life, and also main transportation tools used (Wang et al., 2011). In the source region of Yellow river, pastoralists own a great number of male animals for a long time. But, the quantity of female animals in season is too scarce, thus it greatly reduces the pregnancy rates of livestock especially yak and dairy cattle, and the quantity of livestock. Therefore, the ratio of female animals may objectively reflect the actual local conditions and highlight the issue of livestock structure. Figure 6 indicates that with the continuous increase of ratio of female animals in season, 3 pastoralist's livelihood indexes, i.e. GDP per capita, pastoralist's net income per capita and meat production per capita, present quickly growing trends. The gradient of the curves in Figure 6 shows that the tendency of pastoralist's net income per capita is steep, which representing the strong positive efficiency of ratio of female animals in season on GDP per capita. The positive relationship between ratio of female animals in season and livelihood promotion examined that the higher the ratio of female animals in season is and the more significant efficiency the pastoralist's livelihood will be. This result highlights the importance of management of livestock structure, similar conclusion can be supported by Ho and Azadi (2010)'s study in pastoral areas of Ningxia, China, they emphasized the significance for actively promoting education and training for pastoralists' economic and management awareness. Although different areas of research, it is a common fact that changing traditional perceptions of pastoralists, establishment a scientific development outlook and improvement their ability and level for livestock structure management shall be urgently needed. The focus 
of livelihood promotion shall be placed on the structural improvement of gender, excellent species and the survival rate of breeding. Nevertheless, the strengthening of pastoralist's scientific management awareness is the clearly identified goal of perception innovation.

\subsubsection{Death Rate of Livestock at Mating Age and Pastoralist's Livelihood}

In recent years, great achievements have been made in the ecological engineering like "Si-pei-tao" (Four-Way-Scheme: the "four ways" are to subsidize the building of houses for herders, subsidize shelters for livestock, erect fences, and grow additional fodder) in the source region. The implementation of these projects has vigorously improved the production conditions of animal husbandry, and greatly reduced the death rate of livestock at mating age. However, there is uncertainty about the effects of climate change on the quality of pastures and other resources in this region, but geographical and temporal variability are likely to increase, along with livelihood risks (frequent natural disasters like snow storm, dust storm and drought), the production of animal husbandry in the source region still faces challenge of tremendous natural risks. Moreover, due to serious insufficiency of forage supply in winter and spring, annual and seasonable imbalance of pasture production, and the individual production performance of livestock drops dramatically. Based on this condition, we use the death rate of livestock in at mating age as a comprehensive indicator to measure the technical level and disaster resisting capacity. This indicator highlights the technological levels such as livestock variety improvement and disease prevention technologies. Although the coefficient between death rate of livestock and pastoralist's livelihood is relatively low compared with the other indicators like grazing capacity, slaughter and sold rates of livestock, and composition of female animals in season, the related coefficient (R) is also above 0.78. From Figure 7, it should be clearly recognized that the death rate of livestock at mating age has a reverse relation with livelihood indexes including GDP per capita, net income per capita and meat production per capita, namely, the promoting efficiency of pastoralist's livelihood keeps declining with the increase of death rate of livestock at mating age. Based upon evidence described above, the pastoralists shall strengthen their technological perception and gradually shift the extensive mode of animal husbandry. Then, they may continuously improve the technological content of livestock breeding and optimize the livestock structure. In addition, the development of livestock sheds is also an important approach, indeed, central and local governments do make such efforts all the time but is rarely done so explicitly.

\subsection{Results and Discussion Based on Multiple Factors Model}

In light of the multi-factors model and Table 3, the effects of the composition of female animal in season, death rates of livestock at mating age on livelihood improvement are not significant. Seemingly, this is a result of contradiction compared with the conclusions of the previous analysis. However, this just shows that different elements can have different roles and contributions in the portfolio effects. Compared with the composition of female animal in season, death rates of livestock at mating age, the grazing capacity of livestock, and the slaughter and sold rates of livestock are the determinants in the effects of livelihood improvement. Even though there is a different impact outcome with single factor model, it is common feature that a higher slaughter and sold rates of livestock is associated with an increase in the net income per capita and GDP per capita. The grazing capacity of livestock reduces the net income per capita, and meat production per capita, it is consistent with the result of single factor analysis mentioned above. The ongoing changes in global climatic conditions are exposing communities to ever increasing livelihood risk and threatening sources of livelihood in this area. In other words, overgrazing on grasslands has happened in this area, on the one hand, overgrazing severely hurts the entire grassland biome, on the other hand, overgrazing further affect the livelihoods of local pastoralists. There are also notable differences in the choice priority of pastoralist' perception innovation.

\section{Conclusions and Recommendation}

(1) The improvement of pastoralists' income and material welfare is an important goal and a basic requirement for sustainable livelihood. And the emphasis on the promotion of pastoralists' income and material welfare is a critical path of livelihood sustainability. The changes of grazing capacity, slaughter and sold rates of livestock, ratio of female animals in season and death rate of livestock at mating age (pastoralist's perceptions), in different extent, impact the welfare levels of pastoralist's GDP per capita, net income per capita and meat production per capita (pastoralist's livelihood). Therefore, from the perspective of pastoralist's livelihood promotion, pastoralists shall pay emphasis on the innovation of conventional commodity perception (resisting slaughter rate of livestock and commercialization), the conventional wealth perception of pastoralists (worship the more livestock possession the wealthier), and establishment advanced management perception (focus on structural adjustment and disaster resisting ability). 
(2) From the priority perspective of perception innovation, the slaughter and sold rates of livestock have the strong positive effect on net income per capita and meat production per capita. On the contrary, the grazing capacity of livestock has the strong negative effect. Therefore, special emphasis should be placed on the controlling the grazing capacity of livestock, and promoting the slaughter and sold rates of livestock.

(3) From the perspective of policy and management, governments in all levels shall make a sound environment of perception innovation for pastoralists, enhance the ideological publicity and education of pastoralists, and further strengthen the skill training for pastoralists.

\section{Acknowledgements}

This work was supported by a research grant from the National Basic Research Program of China (Grant No. 2010CB 951704).

\section{References}

Abule, E., Snyman, H. A., \& Smit, G. N. (2005). Comparisons of pastoralists perceptions about rangeland resource utilisation in the Middle Awash Valley of Ethiopia. Journal of Environmental Management, 75(1), 21-35. http://dx.doi.org/10.1016/j.jenvman.2004.11.003

Allsopp, N., Laurent, C., Debeaudoin, L. M. C., \& Samuels, M. I. (2007). Environmental perceptions and practices of livestock keepers on the Namaqualand Commons challenge conventional rangeland $\begin{array}{lllll}\text { management. Journal of Arid } & \text { Environments, } & 70(4), & \text { 740-754. }\end{array}$ http://dx.doi.org/10.1016/j.jaridenv.2006.11.005

An, J. (2001) .The development of animal husbandry economy of Gannan Tibetan Areas. Journal of the Central University for Nationalities (Humane and Social Sciences Edition), 28(4), 48-51(in Chinese).

Bollig, M., \& Schulte, A. (1999). Environmental change and pastoral perceptions: degradation and indigenous knowledge in two African pastoral communities. Human Ecology, 27(3), 493-514. http://dx.doi.org/10.1023/A:1018783725398

Chambers, R. (1986). Sustainable Livelihoods: An Opportunity for the World Commission on Environment and Development. Institute of Development Studies, University of Sussex, Brighton, England, pp. 16-28.

Chambers, R., \& Conway, G. (1992). Sustainable Rural Livelihoods: Practical Concepts for the 21st Century (p. 21). Institute of Development Studies, UK.

Chen, Y. Y., Wang, Y. G., \& Zhou, X. Y. (2008). Research on the status of the desertification and it is driving force in the source region of the Yellow River. Journal of Qinghai University (Nature Science), 26(4), 71-76, 80 (in Chinese).

Clarke, M., \& Islam, S. M. N. (2003). Measuring social welfare: application of social choice theory. Journal of Socio-Economics, 32(1), 1-15. http://dx.doi.org/10.1016/S1053-5357(03)00010-6

Cui, Q. H., Jiang, Z. G., Liu, J. K., \& Su, J. P. (2007). A Review of the cause of rangeland degradation on Qinghai-Tibet Plateau. Pratacultural Science, 24(5), 20-26(in Chinese).

Fang, Y. P., Qin, D. H., \& Ding, Y. J. (2010a). Impact of grassland ecosystem manual intervention on economic welfare-a case of the source region of the Yellow river. Resources and Environment in the Yangtze Basin, 19(9), 1009-1105 (in Chinese).

Fang, Y. P., Qin, D. H., \& Ding, Y. J. (2010b). Changes in stress within grassland ecosystem in the three counties of the source regions of Yangtze and Yellow Rivers. Journal of Arid Land, 2(2), 116-122. http://dx.doi.org/10.3724/SP.J.1227.2010.00116

Fang, Y. P., Qin, D. H., \& Ding, Y. J. (2011a). Frozen soil change and adaptation of animal husbandry: a case of the source regions of Yangtze and Yellow Rivers. Environmental Science \& Policy, 14(5), 555-568. http://dx.doi.org/10.1016/j.envsci.2011.03.012

Fang, Y. P., Qin, D. H., Ding, Y. J., \& Xu, K. Y. (2011b). The impact of permafrost change on NPP and implications: a case of the source regions of Yangtze and Yellow Rivers. Journal of Mountain Science, 8(3), 437-447. http://dx.doi.org/10.1007/s11629-011-1004-3

Ferguson, M. J., \& Bargh, J. A. (2004). How social perception can automatically influence behavior. Trends in Cognitive Sciences, 8(1), 33-39. http://dx.doi.org/10.1016/j.tics.2003.11.004

Hardin, G. (1968). The tragedy of the Commons. Science, 162, 1243-1248. http://dx.doi.org/10.1126/science.162.3859.1243 
Hardin, G. (1998). Essay on sciences and society: extensions of "The tragedy of the Commons". Science, 280, 682-683. http://dx.doi.org/10.1126/science.280.5364.682

Hendricks, H. H., Midgley, J. J., Bond, W. J., \& Novellie, P. A. (2004). Why communal pastoralists do what they do in the Richtersveld National Park. African Journal of Range Forage Science, 21(1), 29-36. http://dx.doi.org/10.2989/10220110409485831

Ho, P., \& Azadi, H. (2010). Rangeland degradation in North China: perceptions of pastoralists. Environmental Research, 110(3), 302-307. http://dx.doi.org/10.1016/j.envres.2009.12.007

Ichibangase, Y., Shen, J., \& Zhao, J. (1998). Social Welfare Theories (p. 2). Shanghai: East China Normal University Press (in Chinese).

Johannesen, A. B., \& Skonhoft, A. (2011). Livestock as insurance and social status: evidence from reindeer herding in Norway. Environmental and Resource Economics, 48(4), 679-694. http://dx.doi.org/10.1007/s10640-010-9421-2.

Kang, Y., Li, Z. C., Tian, H., Liu, R., Shi, X. K., Zhang, J. H., \& Wen, J. (2011). Trend of vegetation evaluation and its response to climate change over the source region of the Yellow River. Climatic and Environmental Research, 16(4), 505-512 (in Chinese).

Kassahun, A., Snyman, H. A., \& Smit, G. N. (2008). Impact of rangeland degradation on the pastoral production systems, livelihoods and perceptions of the Somali pastoralists in Eastern Ethiopia. Journal of Arid Environments, 72(7), 1265-1281. http://dx.doi.org/10.1016/j.jaridenv.2008.01.002

Mapinduzi, A. L., Oba, G., Weladji, R. B., \& Colman, J. (2003). Use of indigenous ecological knowledge of the Maasai pastoralists for assessing rangeland biodiversity in Tanzania. African Journal of Ecology, 41(4), 329-336. http://dx.doi.org/10.1111/j.1365-2028.2003.00479.x

Nan, W. Y. (2002). New thinking of the sustainable development in the Tibetan areas of Qing-Zang Highland. Journal of Qinghai Nationalities Institute (Social Sciences), 28(2), 1-8 (in Chinese).

Ostrom, E., Burger, J., Field, C. B., Norgaard, R. B., \& Policansky, D. (1999). Revisiting the Commons: local lessons, global challenges. Science, 284, 278-282. http://dx.doi.org/10.1126/science.284.5412.278

Pigou, A. (1962). The Economics of Welfare (4th ed., p. 11). Macmillian, London.

Qian, S., Mao, L. X., Hou, Y. Y., Fu, X., Zhang, H. Z., \& Du, J. (2007). Livestock carrying capacity and balance between carrying capacity of grassland with added forage and actual livestock in the Qinghai-Tibet Plateau. Journal of Natural Resources, 22(3), 389-397(in Chinese).

Qinghai Bureau of Statistics and Survey Organization of National Bureau of Statistics. (2011). Qinghai Statistical Yearbook-2010 (pp. 260-321). China Statistics Press (in Chinese), Beijing.

Qin, Q. W. (2007). Economics analysis on idea fights poverty. Theoretic Observation, 5, 16-17 (in Chinese).

Ren, Q. J., Wu, G. L., \& Ren, G. H. (2009). Effect of grazing intensity on characteristics of alpine meadow communities in the eastern Qinghai-Tibetan Plateau. Acta Prataculturae Sinica, 18(5), 256-261 (in Chinese).

Sen, A. (1976). Real national income. Review of Economic Studies, 43(1), 19-39. http://dx.doi.org/10.2307/2296597

Singh, P. K., \& Hiremath, B. N. (2010). Sustainable livelihood security index in a developing country: A tool for

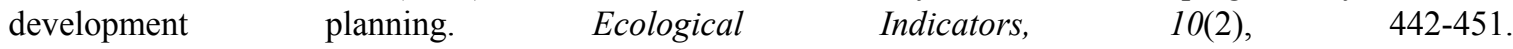
http://dx.doi.org/10.1016/j.ecolind.2009.07.015

Solomon, T. B., Snyman, H. A., \& Smit, G. N. (2004). Cattle-rangeland management practices and perceptions of pastoralists towards rangeland degradation in the Borana zone of south Ethiopia. Journal of Environmental Management, 82(4), 481-494. http://dx.doi.org/10.1016/j.jenvman.2006.01.008

$\mathrm{Su}$, Y. J. (2011). The impact of conversational culture of Zang nationalities on nomadic economy in the Qinghai-Tibet Plateau. Journal of Southwest University for Nationalities (Social Sciences), 6,162-165 (in Chinese).

United Nations General Assembly. (1997). Programme for the Further Implementation of Agenda 21 (p. 11). 19th Special Session, 23-27 June, New York.

Wang, G. X., Li, N., \& Hu, H. C. (2009). Hydrologic effect of ecosystem responses to climatic change in the source regions of Yangtze and Yellow Rivers. Advances in Climate Change Research, 5(4), 202-208 (in 
Chinese).

Wang, H., Ren, J. Z., \& Yuan, H. B. (2006). Study on the desertification mechanism of natural grassland in the source regions of the Yellow River. Acta Prataculturae Sinica, 15(6), 19-15 (in Chinese).

Wang, X., Shi, S. L., \& Zhang, D. G. (2011). Rangeland nomadic culture of the Tibetan ( II )--The culture of rangeland and production. Grassland and Turf, 31(3), 1-4, 14 (in Chinese).

Zeng, Y. N., \& Feng, Z. D. (2009). Analysis of cause mechanism of desertification in headwater area of Yellow River. Journal of Natural Disasters, 18(1), 45-52 (in Chinese).

Zhang, X. W., \& Chen, Q. (2007). Cause analysis on backward perception in western minority-inhabited area of China. Social Science Review, 22(3), 7-9 (in Chinese). 